Brigham Young University Law School

BYU Law Digital Commons

Faculty Scholarship

3-30-2007

\title{
Accommodating Concerns for International Law and Proper Governance
}

David H. Moore

BYU Law, moored@law.byu.edu

Follow this and additional works at: https://digitalcommons.law.byu.edu/faculty_scholarship

Part of the International Law Commons

Recommended Citation

David H. Moore, Accommodating Concerns for International Law and Proper Governance, 101 Am. Soc'Y INT'L PROC. 264 (2007).

This Proceeding is brought to you for free and open access by BYU Law Digital Commons. It has been accepted for inclusion in Faculty Scholarship by an authorized administrator of BYU Law Digital Commons. For more information, please contact hunterlawlibrary@byu.edu. 


\title{
CUSTOMARY INTERNATIONAL LAW AS FEDERAL LAW AFTER SOSA V. ALVAREZ-MACHAIN
}

The panel was convened at 9:00 a.m., Friday, March 30, by its moderator, Martin Flaherty of Fordham University School of Law, who introduced the panelists: Julian Ku of Hofstra University School of Law; David Moore of the University of Kentucky College of Law; Ralph Steinhardt of George Washington University School of International Affairs; and Beth Stephens of Rutgers University.

\section{Introduction: The Path to Sosa}

\author{
By Martin S. Flaherty*
}

With Sosa v. Alvarez-Machain, ${ }^{1}$ the Supreme Court broke nearly twenty-five years of silence concerning modern human rights litigation under what is now commonly known as the Alien Tort Statute (ATS). ${ }^{2}$ Justice Souter's majority opinion answered settled several important questions, not least by confirming the ongoing legitimacy of suits under the ATS. Yet as is true of most of the Court's increasingly frequent forays into foreign relations law, Sosa raised as many questions as it settled.

\section{The ATS, Customary International Law, and Human Rights}

The ATS was enacted by the First Congress in 1789. In slightly modified modern form, it states in its entirety that "The federal district courts shall have original jurisdiction of any civil action by an alien for a tort only, committed in violation of the law of nations or a treaty of the United States." Famously termed by Judge Henry Friendly a "legal Lohengrin,", 3 the statute lay more or less unused until the Second Circuit revived it in Filartiga v. PenaIrala. ${ }^{4}$ In this case the family of a "disappeared" person under a dictatorship in Paraguay brought suit against a former Paraguayan colonel who happened to have immigrated to Brooklyn. Writing for the court, Judge Irving Kaufman reasoned that the family had validly alleged that their son had suffered torture, that torture had evolved into a violation of customary international law, and that the suit could go forward.

Filartiga spurred over 20 years of litigation in which various victims of human rights abuses, aided by groups such as the Center for Constitutional Rights, transformed the statute into a uniquely American mechanism for human rights advocacy. ATS defendants would comprise an international rogues' galley, running from unknown torturers to the president of the Republika Srpska, Radovan Karadzic. ${ }^{5}$ In recent years, ATS suits have become ever more innovative. Plaintiffs have brought actions against defendants within the United States, such as private companies to whom the United States has franchised out the job of maintaining detention centers for aliens. Still others have filed suit against corporations such as Unocal Corp. for aiding and abetting human rights violations by repressive host regimes like Myanmar. ${ }^{6}$

\footnotetext{
* Leitner Family Professor of Law; Co-Director, Leitner Center on International Law and Justice, Fordham Law School; Visiting Professor, Woodrow Wilson School of Public and International Affairs, Princeton University.

${ }^{1} 542$ U.S. 692 (2004).

228 U.S.C. sec. 1350.

${ }^{3}$ ITT v. Vencap, Ltd., 519 F.2d 1001, 1015 (2d Cir. 1975).

${ }^{4} 630$ F.2d 876 (2d Cir. 1980).

${ }^{5}$ Kadic v. Karadzic, 70 F.3d 232 (2d Cir. 1995).

${ }^{6}$ Doe v. Unocal Corp., 395 F.3d 978 (9th Cir. 2003).
} 
At just this point opposition to ATS suits began in earnest. Some skepticism had always existed. Judge Robert Bork, for example, wrote a noted opinion arguing that at best the ATS authorized only suits for violations of the law of nations as it existed in $1789 .{ }^{7}$ Every Circuit Court to have considered the statute nonetheless had approved the ATS in its modern human rights incarnation. Recent suits against corporations, however, raised the stakes and the resistance. Perhaps not coincidentally, the executive branch under the current administration switched sides. Previously, the United States under the Reagan, (first) Bush, and Clinton White Houses filed amicus briefs in support of ATS claims. The present administration, however, took the position that since the statute by its terms speaks only about the federal courts having jurisdiction, it does not create a cause of action. In other words, the ATS was purely jurisdictional. Without more, the previous quarter century of human rights litigation was unauthorized.

\section{The Sosa CASE}

The Supreme Court itself had held aloof from ATS litigation until it granted certiorari in Sosa. The facts could not have been worse from the point of view of the human rights movement. The case involved a doctor, Humberto Alvarez-Machain, who was making his second appearance before the Supreme Court. His case involved the accusation that he had kept alive a U.S. DEA agent in order for that agent to be tortured by drug lords in Mexico. The first time his case came before the Supreme Court was to challenge his abduction by DEA agents for the purpose of bringing him to trial. Then the Court considered whether the Extradition Treaty between the United States and Mexico provided the exclusive means for bringing Mexican suspects to the U.S. for trial, thus effectively prohibiting abduction by U.S. agents for that purpose. Alvarez-Machain lost on that issue, ${ }^{8}$ was tried and acquitted nonetheless. Sosa arose when Alvarez-Machain filed suit against U.S. and Mexican officials seeking damages for his abduction under, among other things, the ATS.

The Court upheld human rights litigation under the ATS in a manner that was both clear and qualified. It rejected the claim that the statute was jurisdictional only, reasoning that Congress in the late eighteenth century would have had the expectation that the courts would have looked to the common law and have applied the common law derived from the law of nations to recognize and apply certain causes of action. As Justice Souter put it, "[ $t]$ he jurisdictional grant is best read as having been enacted on the understanding that the common law would provide a cause of action for the modest number of international law violations with a potential for personal liability at the time.",

There was, however, an apparent catch. The Court further held that any judicial recognition of a cause of action for a modern human rights violation would have to be comparable to those recognized in the late eighteenth century, specifically, piracy, assaults on ambassadors, and violations of safe conduct. In the Court's words: "We think that courts should require any claim based on the present-day law of nations to rest on a norm of international character accepted by the civilized world and defined with a specificity comparable to the features of the 18th-century paradigms we have recognized." 10 Modern violations such as torture, extrajudicial killing, or arbitrary and prolonged detention must in other words satisfy a

\footnotetext{
${ }^{7}$ Tel-Oren v. Libyan Arab Republic, 726 F.2d 774, 798 (D.C. Cir. 1984) (Bork, J., concurring).

${ }^{8}$ United States v. Alvarez-Machain, 504 U.S. 655 (1992).

${ }^{9}$ Sosa, 524 U.S. at 724.

${ }^{10}$ Id. at 725 .
} 
requirement of: (1) generality, which itself echoes one of the principal bases for deriving customary international law rules; and (2) specificity comparable to the eighteenth-century prohibitions. Under these requirements, most of the last twenty years of ATS litigation would seem to be preserved.

But further prudential language may pose difficulty for more novel suits. Justice Souter went on to explain that a series of background "reasons argue for judicial caution" when considering the kinds of claim that might implement the jurisdiction conferred by the early statute. ${ }^{11}$ These reasons drew fairly clearly from scholarship that has expressed skepticism about modern human rights litigation, most notably by Professors Curtis Bradley and Jack Goldsmith. ${ }^{12}$ One reason for caution was the general shift from natural law to positivism that occurred from the eighteenth to the twentieth centuries. Second was a reflection of that shift in Erie v. Tompkins, and the shift away from federal courts making national commonlaw rules. Third, related separation-of-powers concerns counseled that the legislature, rather than the courts, is best suited to establish new causes of action. Fourth, judicial recognition of international law causes of action might have serious consequences for U.S. foreign policy. Fifth and finally, Congress has not authorized modern human rights causes of action beyond the Torture Victim Protection Act. ${ }^{13}$

For his part, Alvarez-Machain may have won the ATS war, but he lost his own battle. He had claimed that his arrest and overnight detention in Mexico violated customary international law. The Court disagreed. Relying mainly on its specificity criterion, the majority concluded that, "a single illegal detention of less than a day, followed by the transfer of custody to lawful authorities and prompt arraignment, violates no norm of customary international law so well defined as to support the creation of a federal remedy." ${ }^{14} \mathrm{He}$ might well have lost even in the absence of the added requirement for specific definition. Under straightforward international law analysis, a norm prohibiting unauthorized arrest and one-day detention likely does not meet either the requirement of generality nor opinio juris.

Precisely because of the ATS, Sosa does not deal directly with the domestic status of customary international law in the absence of a congressional authorization. But the Court did seemingly nod its approval here as well. It briefly noted its jurisprudence affirming judicial application of international law in appropriate instances, including the derivation of international law principles in a common-law fashion. It further noted that his tradition continued after Erie, as manifested in Banco Nacional de Cuba v. Sabbatino ${ }_{15}^{15}$ which "itself did not directly apply international law . . . but neither did it question the application of that law in appropriate cases, and it further endorsed the reasoning of a noted commentator [Philip Jessup] who had argued that Erie did not preclude the continued application of international law in federal courts." 16

\section{LOOKING AHEAD}

Going forward, Sosa presents any number of issues. Two sets stand out. First, what is the future of human rights litigation? The case was a clear victory for international human rights

\footnotetext{
${ }^{11}$ Id.

${ }^{12}$ See, e.g., Curtis A. Bradley \& Jack N. Goldsmith, The Current Illegitimacy of Human Rights Litigation, 66 FORDHAM L. REV. 319 (1997) (arguing that modern international human rights litigation is unauthorized).

${ }^{13}$ Sosa, 542 U.S. at $725-28$.

${ }^{14}$ Id. at 738 .

15376 U.S. 398 (1964).

${ }^{16}$ Id. at 729, n. 18 .
} 
advocacy, yet one with several yellow flags. What exactly will the clear definition rule mean in practice, especially since-unlike the generality requirement-it has no clear parallel in customary international law? And what will either requirement mean for the current wave of litigation? In that context, the Court noted other potential limiting doctrines as well. May non-state actors such as corporations be held liable for aiding and abetting government human rights violations? Should there be an exhaustion of domestic remedies requirement? Should there be case specific deference to the executive branch? ${ }^{17}$

The second set of issues relates to precisely the status of customary international law as federal law in the absence of congressional authorization. Will the Court expressly reaffirm that status in light of recent scholarship to the contrary? And if it does, will a federal commonlaw rule based on international custom trump state law? Executive branch policies? At what level?

Only future, and no doubt Delphic, Supreme Court opinions will tell. In the interim, the views of the experts that follow offer among the best clues to the future.

\title{
ACCOMmodating Concerns for INTERNATIONAL LAW and Proper Governance
}

\author{
By David H. Moore*
}

The debate over the domestic status of customary international law (CIL) implicates two potentially competing concerns-one for the effectiveness of international law and the other for proper governance. On one hand, international law has the potential to help bring order to international relations and constrain improper state behavior. Allowing international law to be enforced in U.S. federal courts like domestic law would presumably help international law achieve these ends. On the other hand, a prominent role for international law in federal courts raises concerns for proper governance as it potentially disrupts traditional separation of powers and federalism protections. The concerns for the effectiveness of international law and for proper governance are often pitted against each other in the debate over CIL's domestic legal status. However, these concerns are not mutually exclusive and the Court in Sosa adopted an approach to CIL's domestic status that accommodates both, leaving room for CIL to play a prominent role in federal courts, while respecting concerns for proper governance.

The Sosa Court achieved this accommodation by indicating that $\mathrm{CIL}$ is subject to the same limitations as post-Erie federal common law generally, thus rejecting the common law exceptionalism advocated by scholars holding the modern position view. Several aspects of the opinion support this assessment.

As an initial matter, Erie played an important role in the Sosa analysis. The Court recognized Erie as a watershed decision that altered our conception of common law making and of the common law powers of federal courts. Erie, of course, did not abolish all common law making by the federal judiciary. However, informed by both separation of powers and

\footnotetext{
${ }^{17}$ See id. at $732-33$.

- Associate Professor, University of Kentucky College of Law. These remarks draw on Curtis A. Bradiey, Jack L. Goldsmith, \& David H. Moore, Sosa, Customary International Law, and the Continuing Relevance of Erie, 120 HaRv. L. Rev. 869 (2007); David H. Moore, An Emerging Uniformity for International Law, 75 GEo. WASH. L. Rev. 1 (2006); and David H. Moore, Setting the Record Straight: Sosa v. Alvarez-Machain and the Debate over Customary International Law, in OUTSOURCING AMERICAN LAw (Jack L. Goldsmith \& John C. Yoo, eds., forthcoming 2007).
} 
federalism concerns, Erie gave rise to a federal common law that is narrow, grounded in positive authorization, and reflective of political branch policy choices.

The changes Erie wrought, the Court indicated, applied to common law based on customary international law. Thus, while the Court acknowledged that its Sabbatino decision had "assumed competence to make judicial rules of decision of particular importance to foreign relations," the Court maintained that "the general practice has been to look for legislative guidance before exercising innovative authority over substantive law." And the Court applied this general rule to common-law incorporation of CIL.

Consistent with this general rule, the relevant portion of the Court's opinion began with a search for congressional intent. Rather than speak of a general common-law status for CIL or of a broad judicial authority to incorporate CIL as common law, the unanimous Court sought to discern congressional intent behind the ATS. Upon concluding that the First Congress intended the ATS to have the immediate effect of providing jurisdiction for a limited set of CIL-based claims available at general law, the Court found limited authority in the federal courts to continue to recognize in common law CIL-based claims that could be heard pursuant to ATS jurisdiction. Critically, the Court grounded this limited authority in positive authorization from the First Congress. Moreover, the Court defined the scope of this continuing authority by reference to congressional intent as well. Thus, modern federal courts may only recognize claims based on CIL norms that resemble in specificity and international acceptance the claims Congress had in mind when adopting the ATS.

When the Court was not focusing on congressional intent or the sea change effected by Erie, it was emphasizing that separation of powers concerns call for great restraint in federal judicial creation of causes of action based on CIL. Judicially created claims threaten "adverse foreign policy consequences" and interference with the political branches' discretion in conducting foreign affairs. ${ }^{2}$ As a result, federal court creation of common-law claims for CIL violations "should be undertaken, if at all, with great caution." 3

Even federalism concerns, often perceived as marginal at best in the foreign affairs context, spoke against broad federal judicial incorporation of CIL. As the Court cautioned, a federal common-law authority to incorporate $\mathrm{CIL}$ that was broader than the one the Court recognized might contravene Erie's "division of responsibilities between federal and state courts." 4

In short, consistent with post-Erie restrictions on federal common law generally, the Court recognized only a limited, congressionally authorized federal judicial authority to create common-law causes of action for violations of CIL. Scholars who find in Sosa a broader common-law status for $\mathrm{CIL}$ or independent authority in the federal judiciary to incorporate $\mathrm{CIL}$ as common law seem to do so as a result of several errors.

Some equate Justice Scalia's concurrence with the view that CIL's role in common law depends on political branch or constitutional authorization and conclude that that view was rejected as Justice Scalia's opinion only garnered two other votes. However, Justice Scalia and the majority agreed that congressional intent was the basis for any federal judicial authority to create common-law causes of action incorporating CIL. They disagreed on whether the First Congress's intent could be effectuated in a world where federal common law was genuine federal law, creating arising-under jurisdiction and preempting state law in

\footnotetext{
${ }^{1}$ Sosa v. Alvarez-Machain, 542 U.S. 692, 726 (2004).

${ }^{2}$ Id. at $727-28$.

${ }^{3}$ Id. at 728 .

${ }^{4}$ Id. at 731, n. 19 .
} 
a way that the general law of the Founding did not. While Justice Scalia believed that the differences between general law and post-Erie common law were too great to effectuate the First Congress's intent through post-Erie common law, the majority believed that a limited authority deriving from that intent could survive the advent of Erie. Importantly, however, neither the majority nor Justice Scalia suggested that $\mathrm{CIL}$ could be incorporated into federal common law without such authorization, so the majority's disagreements with Justice Scalia cannot be taken as an endorsement of an independent common-law status for CIL.

Some who read Sosa as endorsing such a status take selective statements by the Court out of context. For example, the Court at one point states that "no development in the two centuries from the enactment of [the ATS] . . . has categorically precluded federal courts from recognizing a claim under the law of nations as an element of common law." While the conclusion that federal courts are not "categorically precluded" from recognizing common-law claims based on CIL is not, on its own terms, an endorsement of an expansive common-law role for CIL, the statement's context further undermines its support for such a role. To understand that context, it is helpful to divide the ATS portion of Sosa into four sections. The first section is dominated by the search for congressional intent, suggesting the need for positive authorization before federal courts may incorporate $\mathrm{CIL}$ as common law. Having found positive authority, the second section cautions the federal judiciary to exercise that authority with restraint consistent with the limited nature of the authorization, the message of Erie, and the political branches' lead role in both lawmaking and foreign affairs. The third section, from which the above quote hails, responds to Justice Scalia's suggestion in concurrence that the intent of the First Congress could not be translated into a post-Erie world. The fourth section provides guidance on when lower courts may recognize common-law claims for CIL violations. In that section, the Court limits federal judicial incorporation to CIL norms that are as specifically defined and widely accepted as the norms the First Congress considered in enacting the ATS. Moreover, the Court directs lower courts to consider the practical consequences of recognizing a CIL-based claim and, in appropriate cases, whether the plaintiff has exhausted remedies and whether the executive perceives a foreign relations problem from recognition. Further, the Court limits the sources on which courts may rely to find an actionable norm of $\mathrm{CIL}$.

The first, second, and fourth sections of the opinion all emphasize a limited role for the federal judiciary in incorporating CIL into federal common law, raising suspicion about reading statements in the third section as support for a broader common law role for CIL. Moreover, the statements in section three must be divorced from the goal of that section itself to find support for a more expansive common law of CIL. As previously noted, the third section responds to Justice Scalia's conclusion that congressional intent behind the ATS cannot survive Erie. To reach the contrary conclusion, the majority makes the statements at issue. These statements seek to justify the effectuation of the First Congress's intent in a legal environment bereft of federal general law. The engine driving the Court's analysis remains congressional intent. As a result, section three, read in context, supports Sosa's overall message that the federal judiciary may recognize CIL-based common law when authorized to do so by the political branches or the Constitution.

That message leaves room for CIL to play a prominent role in the domestic legal system and even in federal common law, while at the same time respecting concerns for proper

\footnotetext{
${ }^{5}$ Id. at $724-25$.
} 
governance by ultimately leaving the scope of that role to the political branches and the Constitution, not the federal courts.

\title{
A No Decision: Sosa v. Alvarez-Machain and the Debate over the Domestic Status of Customary International Law
}

\author{
By Julian $K u^{*}$
}

While I am very sympathetic to the views on the proper status of customary international law expressed by Professor David Moore and his co-authors, ${ }^{1}$ I do not agree with all of the arguments he has presented here. As much as I would like to agree with him, I do not think that the Supreme Court's decision in Sosa v. Alvarez-Machain ${ }^{2}$ supports the revisionist position as much as he says it does.

In fact, my general take on Sosa is that it does not support either the "revisionist" or "modern" position because the Court's opinion lacks any comprehensive theory of how and why customary international law should be applied by federal courts. Instead, the Sosa decision represents, in my view, a pragmatic but somewhat incoherent ratification of existing caselaw under the Alien Tort Statute based on no particular theory of incorporation. ${ }^{3}$

My talk is divided into three parts. First, I want to offer partial support to Professor Moore's claim that the Sosa decision rejects some components of the modern position, that is to say, the view that customary international law has always formed a component of federal law. However, I will then argue that the rest of the Sosa decision does not really support Professor Moore's revisionist critique. Finally, I will offer some further thoughts on why Sosa represents a "no decision" in the continuing academic debate over the proper status of customary international law in the United States.

I agree with Professor Moore and his co-authors that Sosa represents a vindication of revisionist challenges to the modern position's understanding of the historical status of $\mathrm{CIL}$ prior to Erie v. Tompkins. Prior to Sosa, a number of scholars argued that CIL had always been understood to form part of the "Law of the United States"' as that phrase was used in Articles III and VI of the Constitution. ${ }^{4}$ They pointed to broad statements about international law being part of the "Law of the Land" and such to buttress their claim that CIL is not just common law, but a form of enforceable federal common law and it was always understood as such. Filartiga $v$. Pena-Irala ${ }^{5}$ endorsed this view, at least in passing, by asserting that "CIL has always been part of the federal common law." One consequence of this view is that Erie doesn't matter for CIL because CIL was never part of the general common law that was abolished by Erie.

I hope that, whatever else we say today, everyone on this panel and hopefully in this room, can agree that this claim-that CIL has always been understood to be federal common lawis simply wrong. It's wrong, wrong, wrong. Even the Restatement (Third) of Foreign Relations

\footnotetext{
- Associate Professor of Law, Hofstra University Law School.

${ }^{1}$ See Curtis A. Bradley, Jack L. Goldsmith, \& David H. Moore, Sosa, Customary International Law, and the Continuing Relevance of Erie, 120 HARV. L. REv. 869 (2007).

${ }^{2} 542$ U.S. 692 (2004).

${ }^{3}$ For a more extended critique of the Sosa decision, see Julian Ku \& John Yoo, Beyond Formalism in Foreign Affairs: A Functional Approach to the Alien Tort Statute, 2004 SUP. CT. REv. 153.

${ }^{4}$ See, e.g., Harold Hongju Koh, Is International Law Really State Law?, 111 Harv. L. Rev. 1824, 1825 n. 8 (citing The Nereide, 13 U.S. 9 Cranch) 388, 423 (1815) (1998); Jordan J. Paust, InTERnational LaW as Law OF THE UNITED STATES $30 \mathrm{n} .34$ (1996).

${ }^{5} 630$ F.2d 876 (2d Cir. 1980).
} 
Law of the United States avoided making this historical claim by explicitly acknowledging CIL's non-federal status prior to Erie. ${ }^{6}$ Most importantly, Sosa plainly came down on the side of the revisionists on this point. CIL, the Sosa court acknowledged, was always understood to form part of the general common law, applied by state and federal courts alike, without any explicitly federal status. Sosa started and concluded with this basic premise. ${ }^{7}$ I really hope that at least here, at the Annual Meeting of the American Society of International Law, we can all agree that this historical point has been settled. I hope, therefore, that I never have to attend an ASIL function again, or read an article or case again, that makes this clearly erroneous historical claim.

This is not an inconsequential triumph for the revisionist position. It means that the burden really does shift to the modern position to explain why $\mathrm{CIL}$ is a special kind of "general common law" that is not returned to the states under Erie. By raising this point, the various revisionist scholars have truly helped the courts and academy better understand the origins and history of CIL as part of U.S. law.

On the other hand, this triumph does not mean that Sosa fully supports the revisionist position in the way that Professor Moore and his co-authors suggest. They argue that Sosa essentially adopted a positivist approach to the incorporation of CIL. In this view, CIL is only part of U.S. law unless and until it is incorporated by statute or by the Constitution. Unless I am missing something, however, I do not believe Sosa actually fully embraces this positivist approach.

What exactly is the positive authority for the incorporation of CIL in the context of ATS suits? It is true, as Professor Moore and his co-authors argue, that Sosa focuses heavily on congressional intent in enacting the ATS when determining whether or not to permit lawsuits under CIL to go forward. But the ATS was not read by the Sosa court to incorporate CIL. Rather, the ATS was read to grant jurisdiction to the federal courts and to allow courts to then invoke their otherwise existing constitutional powers to incorporate CIL. So after Sosa, courts are still invoking some inherent authority to incorporate CIL as a form of federal law. I don't see this as a full vindication of the revisionist position, which relies on some positive act, either in congressional legislation or in the Constitution, before CIL may be recognized in U.S. law. When Congress enacts a jurisdictional statute, even a general federal question statute, etc, it is still open for argument after Sosa whether or not courts may invoke their "special super" federal CIL powers.

This leads me to my last point. To me, Sosa is an unsatisfying "no decision" in the ongoing debate over the proper domestic status of CIL in the United States.

Sosa requires lower courts to conduct a two-step analysis when determining whether to recognize a claim under customary international law. First, Congress enacted a jurisdictional statute that does not by itself invoke Congress' power to define and punish the law of nations by creating a cause of action. Second, federal courts have the power to recognize certain limited CIL claims under this statute pursuant to their common-law making powers.

Why do I find this analysis unsatisfying? As I argued earlier, the burden on the Court and the modern position after Erie is to explain why $\mathrm{CIL}$ is now federal law when it was never federal law before. Sosa admits it was not federal law before Erie, but does not provide a

\footnotetext{
${ }^{6}$ See Restatement (Third) of the Foreign Relations Law of the United States, $\$ 111 \mathrm{n} .3$ (1987).

${ }^{7} 542$ U.S. at 724 (acknowledging that at the time of the enactment of the Alien Tort Statute, the accepted conception was of the common law as "a transcendental body of law outside of any particular State but obligatory within it unless and until changed by statute."').
} 
satisfying explanation of how or why rules of general common law became transformed into a set of federal laws independently cognizable by federal courts.

Sosa did not embrace the idea that CIL has always been federal law. It admitted that CIL was applied by federal courts only as a general common law that had no particular federal status. But Sosa also did not to adopt a theory that CIL has been incorporated by any particular constitutional provision, analogous to the incorporation of $\mathrm{CL}$ for interstate disputes and admiralty. Instead, I think the best way of understanding Sosa is as a pragmatic ratification of existing ATS lawsuits. The court appeared to say, "Federal courts have been doing this thing under the ATS. There is no statutory or obvious constitutional authority for them to do this, but there doesn't seem to be any great harm either. So let them keep going, but let's be careful out there, OK?"

I agree with the Court that this is not a bad result and I understand why this would be an attractive option. As a policy matter, ATS lawsuits are relatively unimportant and unproblematic compared to other types of litigation in U.S. courts. But the Court's approach in Sosa, provides little guidance for what I think are the two most important questions remaining after Sosa.

First, does Sosa mean that CIL is a form of law that preempts state court interpretations of CIL? Are state courts bound by all the rules governing the sources of CIL that the Court identified? By focusing on congressional intent in enacting a jurisdictional statute and flatly rejecting the view that $\mathrm{CIL}$ is pure federal law, it remains very unclear whether state courts have lost CIL powers under Erie or whether, like conflict-of-laws rules, they retain broad concurrent authority to develop their own rules of CIL.

Second, does Sosa mean the President is bound by CIL because it is a special form of federal common law? Again, I don't think the Sosa court provided an answer to this question because it refused to adopt a clear theory of CIL. I believe that the President is not bound, at least in the sense of domestic law, but Sosa does not appear to answer this question one way or the other.

Let me conclude by pointing out how important the revisionist movement has been for this area of law. Prior to the revisionist movement, the understanding of $\mathrm{CIL}$ as domestic law was fuzzy at best. Here is a great example from Restatement Third: "It is now established that customary international law in the United States is a kind of federal law, and like treaties and other international agreements, it is accorded supremacy over State law by Article VI of the Constitution." ${ }^{8}$ If Sosa accomplished very little, it at least proved that almost nothing in this short section is "established." It is not established that CIL is a kind of federal law binding on the States and it is not established that cases arising under CIL arise under "laws of the United States" generally. We have the revisionists to thank for that.

\section{Sosa, the federal Common Law and Customary International Law: Reaffirming the Federal Courts' Powers}

$$
\text { By Beth Stephens* }
$$

Since the framing of the Constitution, the federal courts have had the power to apply customary international law as a rule of decision and to recognize a common-law cause of action for violations of international law. In a 1997 law review article, Professors Curtis

\footnotetext{
${ }^{8}$ Restatement (Third) of the Foreign Relations law of the United States, § 111.

- Professor of Law, Rutgers-Camden School of Law.
} 
Bradley and Jack Goldsmith challenged this traditional understanding of federal judicial powers. ${ }^{1}$ They argued that federal courts could not apply customary international law in the absence of explicit authorization from the legislative or executive branches.

Bradley and Goldsmith framed the debate as one between "revisionists" and "the modern position." As William Dodge has demonstrated, however, the debate is more properly characterized as one between revisionists and "traditionalists.", The framers who drafted the Constitution recognized the federal courts' power to recognize and apply international law norms, a position that reflected the importance of international law at the time the Constitution was ratified. In 2004 in Sosa v. Alvarez-Machain, the Supreme Court reaffirmed the modern relevance of this traditional understanding of the federal courts' common-law power to apply customary international law. ${ }^{3}$ The Court recognized this as a fundamental judicial power, not dependent on the authorization of the other branches of government.

Bradley and Goldsmith depicted the debate as one between two monolithic, opposing doctrines. This simplified view, repeated in their recent article with Professor David Moore, ${ }^{4}$ claims that advocates of the traditional approach support the "wholesale incorporation" of customary international law into federal law. ${ }^{5}$ To the contrary, the federal common law is by nature a selective body of law, applied by federal courts when appropriate to the cases before them. In some cases, federal courts apply customary international law as part of that federal common law.

An understanding of the role of customary international law as federal common law begins with the recognition of the status of the common law from the time of the ratification of the Constitution through the first 150 years of the nation. Prior to the Supreme Court's 1938 decision in Erie R.R. Co. v. Tompkins, ${ }^{6}$ federal courts routinely applied international law as a form of common law, without the need for authorization from the executive or legislative branches. Bradley and Goldsmith argued that all pre-Erie common law was part of the general common law that the Supreme Court abandoned in Erie. As I have written elsewhere, however, pre-Erie common law had several strands, some of which trespassed upon areas constitutionally delegated to the states, and some of which addressed uniquely federal issues. ${ }^{7}$ Erie rejected the federal court practice of developing common-law rules in areas subject to state control. But in many pre-Erie cases the federal courts had recognized the need for a truly federal common law to govern areas assigned by the Constitution to the federal government, areas as to which Congress had not legislated or had left gaps. Although not labeled federal common law, the federal rules governing these cases operated as federal common law does today. Erie did not discard the federal strands of the common law but, rather, freed that law from the taint of the general common law and enabled it to function as truly federal common law.

\footnotetext{
${ }^{1}$ Curtis A. Bradley \& Jack L. Goldsmith, Customary International Law as Federal Common Law: A Critique of the Modern Position, 110 Harv. L. Rev. 815 (1997).

${ }^{2}$ William S. Dodge, Customary International Law and the Question of Legitimacy, 120 HARv. L. REv. 19 (2007).

${ }^{3}$ Sosa v. Alvarez-Machain, 542 U.S. 692 (2004).

${ }^{4}$ Curtis A. Bradley, Jack L. Goldsmith \& David H. Moore, Sosa, Customary Intemational Law, and the Continuing Relevance of Erie, 120 HARV. L. REV. 869 (2007).

${ }^{5}$ See, e.g., id. at 873 (describing the "modern position" as holding "that CIL is incorporated wholesale into the U.S. legal system as federal common law.").

${ }^{6} 304$ U.S. 64 (1938).

${ }^{7}$ See Beth Stephens, The Law of Our Land: Customary International Law as Federal Law After Erie, 66 ForDHAM L. REv. 393 (1997).
} 
In Sosa, the Supreme Court ruled decisively that nothing in Erie deprived the federal courts of one particular aspect of this federal common power, the power to recognize a federal common-law cause of action for violations of international law. Sosa involved the proper interpretation of the Alien Tort Statute, a 1789 statute that grants federal courts jurisdiction over claims for "a tort only, in violation of the law of nations." 8 The Court held that Congress enacted the ATS on the understanding that the federal courts would use their common-law power to recognize a private cause of action for a small number of international law violations: "The First Congress, which reflected the understanding of the framing generation and included some of the Framers, assumed that federal courts could properly identify some international norms as enforceable in the exercise of $\S 1350$ jurisdiction."

Sosa recognized that nothing since 1789 had eroded that power:

[N]o development in the two centuries from the enactment of $\S 1350$ to the birth of the modern line of cases beginning with Filártiga v. Pena-Irala, 630 F.2d 876 (2d Cir. 1980 ), has categorically precluded federal courts from recognizing a claim under the law of nations as an element of common law. ${ }^{10}$

In particular, nothing in Erie undermined this historic judicial power: "We think it would be unreasonable to assume that the First Congress would have expected federal courts to lose all capacity to recognize enforceable international norms simply because the common law might lose some metaphysical cachet on the road to modern realism."11

Despite Sosa's affirmation of the traditional approach, a recent article by Professors Moore, Bradley, and Goldsmith makes the startling claim that Sosa affirmed their view of the relationship of customary international law and federal common law. They base this claim on their repeated assertion that Sosa held that the ATS "authorized" the federal courts to recognize common law claims for some violations of customary international law ${ }^{12}$-language that is nowhere to be found in the Sosa opinion.

This narrow misreading of Sosa reverses its basic holding. Sosa does not support the view that the legislative or executive branch must "authorize" the application of customary international law applies in federal courts. The Court took pains to make clear that such authorization is not necessary. The power to recognize a common-law cause of action for violations of international law is a judicial power. Congress enacted the ATS on the understanding that the courts would exercise that common-law power. The difference is not just semantic, because it addresses the judiciary's constitutional power. The Supreme Court over the past few years has repeatedly reaffirmed judicial power in the face of executive branch overreaching. Sosa is best understood as a piece of that larger effort.

That the Sosa majority did not hold that congressional "authorization" is necessary becomes even clearer from reading the concurring opinion of Justice Scalia, who cited the early Bradley and Goldsmith article and clearly agreed with them that such authorization is necessary. ${ }^{13}$ The majority, however, strongly rejected this view.

${ }^{8} 28$ U.S.C. $\$ 1350$

${ }^{9}$ Sosa, 542 U.S. at 730.

${ }^{10}$ Id. at $724-25$.

${ }^{11}$ Id. at 730 .

${ }^{12}$ See, e.g., Bradley et al., at 873 ("'The Court in Sosa held that the ATS authorized federal courts to recognize federal common law causes of action for a narrow class of CIL violations.").

${ }^{13}$ Justice Scalia complains bitterly that the majority permits judges "to create rights where Congress has not authorized them to do so ...." Sosa, 542 U.S. at 747 (Scalia, J., concurring in part). 
Although the revisionist position has changed over time, it is useful to recognize some of its more startling claims. Bradley and Goldsmith argued in their early article that the common law has no role in federal courts because the only applicable law is that enacted by the legislative and executive branches. As a policy matter, they criticized common-law lawmaking as anti-democratic. They drew attention to a change in the nature of customary international law, arguing that modern international law addresses areas-human rights violations such as torture, for example-that were not the subjects of international regulation in the eighteenth century. As a result of that change, they argued, modern customary international law has no place in the common law developed by the courts without authorization from the political branches.

The Court in Sosa rejected the revisionist argument that the federal courts should forgo their traditional power to recognize federal causes of action for violations of international law. Although the decision to use common-law power to apply an international rule or to recognize a cause of action for a violation of international law should take into account guidance from the political branches, it is not bound by them. Cautionary factors call attention to both separation of powers and federalism concerns. But the decision is for the courts.

Finally, although the executive branch's views may be relevant in some cases, the Sosa Court pointedly did not look to the executive branch for guidance in this case. Sosa flatly rejected what the executive had to say about the ATS, federal common law, and customary international law. Similarly, it flatly rejected what Bradley and Goldsmith had to say about the ATS and the role of customary international law as federal common law.

\section{The Traffic Light Theory of Sosa v. Alvarez-Machain}

\section{By Ralph G. Steinhardt}

One strikingly shared interpretation of the inkblot that is Sosa v. Alvarez-Machain is that everybody - except me-thinks that they won the case. As Alvarez-Machain's co-counsel with Paul Hoffman, I am fairly certain that our client lost his suit for damages under the Alien Tort Statute ("ATS") against one of his kidnappers. By contrast, judging from the tenor of their forthcoming article in the Harvard Law Review, the self-styled "revisionists" are fairly certain that they won Sosa, finding in the Court's rhetoric of caution a complete vindication of their approach. I think that that interpretation requires an Olympian detachment from the fact that "revisionist" arguments were fully and passionately advanced by the government, by Sosa, and by their amici in the litigation and were not adopted in the majority opinion. They dominate Justice Scalia's concurrence, but Professor Stephens is right that the majority opinion simply does not adopt the full-throated "revisionism" advanced by our opponents in court.

On the other hand, most human rights lawyers think that they won the war and lost the battle in Sosa, because the Court endorsed the power of federal courts to infer a cause of action from customary international law-the very heart of Bradley and Goldsmith's "revisionist" attack on Filartiga and its progeny ten years ago.' As Justice Scalia rightly observed, of the hundreds of ATS decisions in the federal courts over the last quarter century,

\footnotetext{
* Arthur Selwyn Miller Research Professor of Law and Director of the Oxford Programme in International Human Rights Law, The George Washington University Law School.

${ }^{1}$ Curtis Bradley \& Jack Goldsmith, Customary International Law as Federal Common Law: A Critique of the Modern Position, 110 HaRv. L. Rev. 815 (1997).
} 
the only decision disapproved by the majority was Alvarez-Machain itself, suggesting that the hard-line "revisionist" critique of ATS litigation rested more on caricature than portrait.

At some point, a legal theory from even the most admired academics must either make a difference in the decided cases, or it must fall away. So, from the Proof-of-the-Pudding Department, let me glance at the way Sosa has been interpreted in the courts, rather than in the journals, and offer a "traffic light" theory of Sosa that brings greater coherence to the post-Sosa jurisprudence than Professor Ku has described.

First, Sosa's “red light:" at a minimum, Alvarez-Machain lost his case, because, according to the Court, he did not suffer an arbitrary detention as defined at international law: "[a] single illegal detention of less than a day followed by a transfer of custody to lawful authority and a prompt arraignment violates no norm of customary international laws so well defined as to support the creation of a federal remedy." I think that the Court radically sanitized the facts of his kidnapping and abused precedent in assessing the legal status of certain human rights instruments, but we know from cases after Sosa that an arbitrary detention that does meet the international standard is fully actionable under the ATS. ${ }^{2}$

Sosa's "yellow light" is its rule of evidence that an international norm can be actionable under the ATS only if it is "specific, universal, and obligatory." Of course, the courts have never been allowed to make something up and call it customary international law, but Sosa cautions courts in future ATS litigation to determine whether a human rights claim "rest[s] on a norm of international character accepted by the civilized world and defined with a specificity comparable to the features of the 18th-century paradigms we have recognized." The fact that the Court cited Filartiga, Karadzic, and Marcos with approval suggests that certain norms do satisfy this demanding but traditional standard, the pedigree of which can be traced to the Supreme Court's decision in Paquete Habana ${ }^{3}$ and its antecedents. Thus, claims for torture, genocide, violations of the laws of war, crimes against humanity, slavery, etc., clearly satisfy Sosa's rule of evidence. The Court's five reasons for caution in adapting the law of nations to private rights-discussed in detail by other panelists-are ad hoc considerations to be taken into account in deciding whether the rule of evidence has been satisfied in a particular case or not. The Court explicitly rejected our opponents' argument that these case-by-case concerns erected some prophylactic barrier to ATS litigation. In short, Sosa adopts a new interpretation of the ATS only according to those academics and practitioners who had systematically overstated the threat posed by the ATS or the creativity of judges rendering decisions under it.

Sosa's "green light" is that, once the demanding and traditional rule of evidence is satisfied, the courts may do the one thing that the "revisionists" said was illegitimate, viz., infer a cause of action from customary international law. In the three years since Sosa was decided, not a single ATS plaintiff has lost on the ground that Erie ${ }^{4}$ bars the inference of a cause of action from customary international law, as the "revisionists" claimed.

Since 2004, plaintiffs have tended to lose when their lawyers were overly creative in asserting that a particular norm had achieved the status of customary international law, but that was true even before Sosa, when it was established, for example, that environmental torts are "out," as is garden-variety fraud. We knew pre-Sosa that international law does not have the equivalent of full First Amendment freedoms and that the fairness of state

\footnotetext{
2 Jean v. Dorelien, 431 F.3d 776 (11th Cir. 2005).

${ }^{3} 175$ U.S. 677 (1900).

${ }^{4}$ Erie R.R. Co. v. Tompkins, 304 U.S. 64 (1938).
} 
lottery distribution systems is out, as is transnational defamation. Post-Sosa, we know that the safe conduct norm does not cover cross-border parental abduction of a child ${ }^{5}$ and that the use of herbicides in war is not prohibited by international law. ${ }^{6}$ We also know post-9/ 11 that the state secret privilege may require dismissal ${ }^{7}$ and that other procedural obstacles, like the political question doctrine ${ }^{8}$ or forum non conveniens, can derail an ATS case, just as they can derail any transnational civil litigation.

On the other hand, the great bulk of human rights claims that were justiciable pre-Sosa remain justiciable post-Sosa: torture, genocide, extrajudicial killing, torture, arbitrary detention, crimes against humanity, cruel and inhuman treatment, among others. ${ }^{9}$ To that list, the Ninth Circuit has added racial discrimination, ${ }^{10}$ and the Seventh Circuit found the Sosa test satisfied in a consular notification case, because the Vienna Convention on Consular Relations is self-executing. ${ }^{11}$

The most significant issue currently being litigated is the liability of corporations for human rights violations, especially the contours of conspiracy and aiding-and-abetting liability. ${ }^{12}$ At this writing, some of the appellate cases are sub judice, like the South African Apartheid cases, and some are at various stages of briefing, like Talisman. To oversimplify a position I have taken in print and in litigation, there are two circumstances in which corporations will and should face liability under the ATS: (1) when they commit one of the handful of wrongs that do not require state action (genocide, slavery, and certain war crimes); and (2) when, by virtue of their relationship with a state actor, they are complicit in a state's wrong. There is an international legal standard for aiding and abetting liability, and, even if there were not, there are general principles of law common to domestic legal systems, where secondary liability for aiding and abetting is clearly established, suggesting the inference of international law on that issue. And, even if these sources were not available, Sosa requires that common tort law, like Section 802 of the Restatement of Torts, define the dimensions of secondary liability and that international law define the underlying norm.

I will close by observing that the "revisionist" interpretation of Erie has made no difference in the ATS decisions of courts (as distinct from the decisions of a handful of judges writing for themselves) either before or after Sosa. And even if the revisionist view of Erie had any

\footnotetext{
${ }^{5}$ Taveras v. Taveraz, 477 F.3d 767 (6th Cir. 2007).

${ }^{6}$ In re Agent Orange Product Liability Litigation, 373 F.Supp.2d 7 (E.D.N.Y. 2005).

${ }^{7}$ El-Masri v. U.S., 479 F.3d 296 (4th Cir. 2007).

${ }^{8}$ See, e.g., Doe v. Exxon Mobil Corp., 473 F.3d 345 (D.C. Cir. 2007); Joo v. Japan, 413 F.3d 45 (D.C. Cir. 2005).

${ }^{9}$ See, e.g., Doe v. Saravia, 348 F.Supp.2d 1112 (E.D.Cal. 2004); Jean v. Dorelien, 431 F.3d 776, 778 (11 th Cir. 2005); Chavez v. Carranza, 413 F.Supp.2d 891, 899 (W.D.Tenn. 2005); Doe v. Qi, 349 F.Supp.2d 1258 (N.D.Cal. 2004); Almog v. Arab Bank, PLC, 471 F.Supp.2d 257 (E.D.N.Y. 2007); Cabello v. Fernandez-Larios, 402 F.3d 1148 (11th Cir. 2005); Elmaghraby v. Ashcroft, _ F. Supp. 2d _, 2005 WL 2375202 (E.D.N.Y. 2005). Cf., enslavement and crimes against humanity from 1890 through 1915 , Hereros ex rel. Riruako v. Deutsche AfrikaLinien Gmblt \& Co., _ F.3d _, 2007 WL 1066949 (3rd Cir. 2007). In order for torture to be actionable, it must be committed by state actors. Saleh v. Titan Corp., 436 F.Supp.2d 55 (D.D.C. 2006). Post-Sosa, the courts have split on the issue of whether the Torture Victim Protection Act occupies the field. Compare Enahoro v. Abubakar, 408 F.3d 877 (C.A.7th Cir. 2005) with Chavez v. Carranza, 413 F.Supp.2d 891, 899 (W.D.Tenn. 2005).

${ }^{10}$ Sarei v. Rio Tinto, PLC, _ F.3d _, 2007 WL 1079901 (9th Cir. 2007).

${ }^{11}$ Jogi v. Voges, 480 F.3d 822 (C.A.7 2007).

${ }^{12}$ See, e.g., Sarei v. Rio Tinto, PLC, __ F.3d __, 2007 WL 1079901 (9th Cir. 2007); Almog v. Arab Bank, PLC, F.Supp.2d, 2007 WL 214433 (E.D.N.Y. 2007); Presbyterian Church of Sudan v. Talisman Energy, Inc., 453 F.Supp.2d 633 (S.D.N.Y., 2006); Kiobel v. Royal Dutch Petroleum Co., 456 F.Supp.2d 457 (S.D.N.Y. 2006); In re Sinaltrainal Litigation, 474 F.Supp.2d 1273 (S.D.Fla. 2006); Bowoto v. Chevron Corp., _ F. Supp. 2d _, 2006 WL 2455752 (N.D.Cal. 2006); Aldana v. Del Monte Fresh Produce, N.A., Inc., 416 F.3d 1242 (11th Cir. 2005); Mujica v. Occidental Petroleum Corp., 381 F.Supp.2d 1164 (C.D.Cal. 2005); Corrie v. Caterpillar, Inc.. 403 F.Supp.2d 1019 (W.D.Wash. 2005); Abdullahi v. Pfizer, Inc., _ F.Supp.2d _, 2005 WL 1870811 (S.D.N.Y. 2005); In re South African Apartheid Litigation, 346 F.Supp.2d 538 (S.D.N.Y. $\overrightarrow{2004}$ ).
} 
traction in the cases, the revisionists are obliged to identify what part of Erie converts international law into state law. ${ }^{13}$ The constitutional dimension to Erie fundamentally distinguishes international law under the ATS from the common-law tort rules that were at stake in that case: there is no reservation of state power under the Tenth Amendment with respect to international law that is in any way comparable to the limitations on the federal government that were at the heart of the Erie litigation. There is nothing in the invisible radiations of the Tenth Amendment that would suggest that international law has to be state law. And, in response to Professor Ku's point that state courts can interpret international law and that there are some examples of the Supreme Court not reviewing these decisions, I think that that is entirely too thin a reed to support the revisionist argument: state courts must interpret international law under the Supremacy Clause, and, if they get it right, there is no reason for the Supreme Court to review it. The fact that states also apply international law, as Professor Ku observes, is entirely consistent with the idea that it is still an element of federal common law and, as Sosa demonstrates, does not require a congressional act to make it actionable.

${ }^{13}$ Harold Hongju Koh, Is Intermational Law Really State Law?, 111 HaRv. L. Rev. 1824 (1998). 
